\title{
Application of Optical Sensors for Nitrogen Management in Chrysanthemum
}

\author{
Amir Ali Khoddamzadeh ${ }^{1}$ \\ Department of Earth \& Environment, Florida International University, \\ 11200 SW 8th Street, AHC-5 391, Miami, FL 33199
}

\author{
Bruce L. Dunn \\ Department of Horticulture and Landscape Architecture, Oklahoma State \\ University, 358 Agricultural Hall, Stillwater, OK 74078-6027
}

Additional index words. garden mum, NDVI, SPAD, atLEAF, 'Jacqueline Yellow', 'Amico Bronze'

\begin{abstract}
Nitrogen (N) is an important component of proteins and chlorophyll, and has been correlated with optical sensors as a means to determine $N$ status during crop production. In this experiment, chrysanthemum 'Amico Bronze' and 'Jacqueline Yellow' had initial controlled-release fertilizer rates of $0,5,10,15$, or $20 \mathrm{~g}$. Normalized Difference Vegetation Index (NDVI), Soil Plant Analytical Development (SPAD), and atLEAF sensor readings were taken at 10, 17, 24, 31, 38, and 45 days after adding initial fertilizer treatments (DAT). NDVI was correlated with leaf $N$ concentration at all sampling dates except 17 DAT. Values for NDVI increased linearly up to 31 DAT for all treatments then plateaued at 45 DAT. Values for SPAD were only correlated with leaf $N$ at 24 DAT, whereas, NDVI was correlated as early as 10 DAT. The atLEAF sensor was not correlated with leaf $N$ at any sampling date. With weeks combined, correlation analysis showed correlations among leaf $\mathrm{N}$ and fertilizer rates, fertilizer rates and SPAD, and SPAD with NDVI and atLEAF. Thirty-one days after initial fertilizer treatment, 10 pots per treatment per cultivar were supplemented as following: $15 \mathrm{~g}$ supplemented to the $0 \mathrm{~g}$ treatment, $10 \mathrm{~g}$ to the $5 \mathrm{~g}$ treatment, and $5 \mathrm{~g}$ to the $10 \mathrm{~g}$ treatment at $31 \mathrm{DAT}$. With supplemented fertilizer treatments (SFTs), NDVI increased weekly until 45 DAT for 'Amico Bronze', while SPAD values did not increase in any treatments. The greatest atLEAF values occurred with $10(+5) \mathrm{g}$ and $0(+15) \mathrm{g} N$ in both cultivars. All sensor readings were only taken on leaves without any flowers. The greatest number of flowers, plant height, and shoot dry weight occurred with $10(+5) \mathrm{g}$ of additional $\mathrm{N}$, but no differences occurred between $5(+10) \mathrm{g}$ and $0(+15) \mathrm{g}$ for height and shoot dry weight. No correlations existed between fertilizer rates, SPAD, NDVI, and leaf $\mathrm{N}$ for SFT in either cultivar. In summary, results indicated that NDVI values correlated greater $(P \leq 0.05$ and $P \leq 0.01)$ with leaf $N$ than SPAD and atLEAF chlorophyll sensors. Supplemental fertilizer application improved plant quality in terms of number of flowers, plant height, and shoot dry weight for all treatments, indicating that SFT could be used to correct $\mathrm{N}$ deficiency during crop production; however, not in combination with nondestructive sensor readings because of inconsistencies in the ability of all three sensors to separate among fertilizer treatments during a short production schedule.
\end{abstract}

Dendranthema ×grandiflorum (Ramat.) Kitam. spp. (commonly referred to as chrysanthemums or garden mums) are an important crop ranking second in potted production after roses (Xia et al., 2006). In the United States, total wholesale value of potted chrysanthemums was more than $\$ 125$ million in 2012 (U.S. Department of Agriculture, 2013). Chrysanthemums have a high $\mathrm{N}$ requirement (Lunt and Kofranek, 1958). Nitrogen is a macronutrient that affects plant chlorophyll content (Moorby and Besford, 1983), which can be used to define the growth status and leaf $\mathrm{N}$ content in plants (Dunn

Received for publication 21 Oct. 2015. Accepted for publication 26 Apr. 2016.

${ }^{1}$ Corresponding author. E-mail: akhoddam@fiu. edu. et al., 2015; Hardin et al., 2012; Seemann et al., 1987; Wang et al., 2012a, 2012b). One method of measuring $\mathrm{N}$ content in plants consists of harvesting leaves that are then dried and chemically analyzed. This process takes time, is expensive, and most importantly may not meet grower needs for adjusting $\mathrm{N}$ for the current crop. Use of nondestructive handheld sensors can provide an instant indication of leaf chlorophyll that then can be correlated with leaf N (Filella et al., 1995). For several horticultural crops, leaf $\mathrm{N}$ and chlorophyll were strongly correlated using a SPAD chlorophyll meter (Dunn et al., 2015; Hardin et al., 2012; Shaahan et al., 1999; Wang et al., 2004, 2012b; Westerveld et al., 2003; Zanin and Sambo, 2006). Optical sensing of $\mathrm{N}$ in leaves is based on chlorophyll spectral response to light. Chlorophyll absorbs blue $(450 \mathrm{~nm})$ and red light $(650 \mathrm{~nm})$ and reflects near infrared (NIR) light (>750 nm). The intensity of transmitted and/or reflected light at these wavelengths can be used to form empirical relationships, which estimate chlorophyll concentration (Hardin et al., 2012; Richardson et al., 2002). A SPAD-502 (SPAD) meter measures light intensity (650 and $940 \mathrm{~nm}$ ) transmitted through a $2 \mathrm{~mm}$ by $3 \mathrm{~mm}$ area of a leaf. The $650-\mathrm{nm}$ wavelength coincides with the spectral region associated with maximum chlorophyll activity, whereas the transmittance at $940 \mathrm{~nm}$ is used as a reference to compensate for factors such as leaf moisture content and thickness (Blackmer and Schepers, 1995; Hawkins et al., 2007). The SPAD meter calculates a unitless value between 1 and 100 that correlates with leaf chlorophyll concentration (Hardin et al., 2012). Besides SPAD, atLEAF is a newly developed chlorophyll sensor that is a less expensive alternative to the SPAD meter. Both meters measure transmittance through leaf surfaces in wavelengths associated with chlorophyll, thus both can provide an indirect method for determining N status. Results from six species showed strong correlations among laboratory leaf chlorophyll content, SPAD, and atLEAF value (Zhu et al., 2012). In addition, Wang et al. (2012b) demonstrated that a SPAD chlorophyll meter and a pocket NDVI unit were able to estimate $\mathrm{N}$ status in potted geraniums.

NDVI is an indicator of the density of chlorophyll, biomass, and plant nutrition in leaf tissue calculated from the red and NIR bands: $\mathrm{NDVI}=(\mathrm{NIR}-\mathrm{RED}) /(\mathrm{NIR}+\mathrm{RED})$. The NDVI sensors can generate values between -1 and +1 , where vegetated areas in general yield high positive values, while nonvegetated background values produce lower or negative values (Johansen and Tømmervik, 2014). Use of an NDVI index is widely accepted in large-scale agronomic field production and some horticultural crops (Baghzouz et al., 2007; Bell et al., 2004; Carrillo, 2006; Clay et al., 2006; Dunn et al., 2015; Eitel et al., 2008; El-Shikha et al., 2007; Penũelas et al., 1994; Wang et al., 2012a; Xiong et al., 2007), but has limited reports for greenhouse settings. The objectives of this study were 1) to assess if sensor (SPAD, atLEAF, and NDVI) readings could be used to predict $\mathrm{N}$ status during chrysanthemum production and 2) to investigate if plant growth and flowering would benefit from supplemental fertilizer applied late in production when sensor readings would be taken.

\section{Materials and Methods}

Plant material and growth conditions. Chrysanthemum 'Jacqueline Yellow' and 'Amico Bronze' were obtained as rooted cuttings from Park Seed Co. (Greenwood, SC) on 15 July 2013. Plants were transplanted into standard $15.24 \mathrm{~cm}$ diameter and $1.35 \mathrm{~L}$ volume pots with $\approx 0.35 \mathrm{~kg}$ Metro-Mix media (Sun Gro Horticulture, Bellevue, WA) the following day. Three equally spaced plants were placed in each pot and plants were grown in the Department of 
Horticulture and Landscape Architecture Research Greenhouses in Stillwater, OK under natural photoperiods. Temperature was set at $18{ }^{\circ} \mathrm{C} / 21{ }^{\circ} \mathrm{C}$ day/night with a photosynthetic photon flux density range of 800 to $1250 \mu \mathrm{mol} \cdot \mathrm{m}^{-2} \cdot \mathrm{s}^{-1}$ at $1200 \mathrm{HR}$.

Growth conditions. On 19 July 2013, fertilizer treatments of either $0,5,10,15$, or $20 \mathrm{~g}$ of $16 \mathrm{~N}-9 \mathrm{P}-12 \mathrm{~K}$ (Osmocote ${ }^{\circledR}$ Plus, 5 to 6 month product, The Scotts Co., Marysville, $\mathrm{OH})$ controlled-release fertilizer were applied on the surface of each pot and tap water was then used during irrigations. Pots were drip irrigated at a rate that allowed media saturation and leaching to be estimated at $\approx 25 \%$. Nitrogen treatments were designed to produce plants with $\mathrm{N}$ status ranging from deficient to excessive based on fertilizer bag recommendations. The experiment, consisting of five treatments and two cultivars was replicated 20 times with single pot replications (three plants in each pot) in a completely randomized design (CRD).

Effects of fertilizer rates on NDVI, atLEAF, and $S P A D$ values. Individual plants were scanned from 10 pots per treatment for NDVI (Trimble, Sunnyvale, CA), atLEAF chlorophyll meter (FT Green LLC, Wilmington, DE), and a SPAD-502 chlorophyll meter (SPAD-502, Konica Minolta, Japan) every $7 \mathrm{~d}$ for 6 weeks up to flowering but not during flowering. During measurements, the NDVI sensor was placed $45 \mathrm{~cm}$ above the plant canopy, giving the sensor a circular field of view with a diameter of $\approx 12 \mathrm{~cm}$. Bare wet soil has an NDVI value of 0.42 at $45 \mathrm{~cm}$, and can influence NDVI readings; therefore, sensor readings were initiated at 10 DAT to minimize background effects. For each pot, SPAD and atLEAF measurements were collected from four mature leaves from the bottom to middle area of the plant. Leaf foliar analysis consisted of collecting the leaves used for the SPAD and atLEAF meter with 10 pots bulked per treatment per cultivar for an average total-N per treatment each week. Leaf samples were analyzed for total-N content $\left[\mathrm{g} \cdot \mathrm{kg}^{-1}\right.$ dry weight (DW)] by the Soil, Water, and Forage Analytical Laboratory at Oklahoma State University. Total $\mathrm{N}$ was determined by dry combustion using a LECO TruSpec Carbon and Nitrogen Analyzer (LECO Corporation, St. Joseph, MI). At the end of the study, measurements on plant height (from the top of the pot to the highest point), width (average of two perpendicular measurements), flower diameter, number of flowers, and shoot dry weights (stems cut at soil level) were recorded. To obtain shoot dry weight, samples were dried in an oven (Precision Scientific, Winchester, VA) for $48 \mathrm{~h}$ at $70{ }^{\circ} \mathrm{C}$ (Ali, 2010).

SFT conditions. On 19 Aug. 2013 (31 DAT) half of the $0 \mathrm{~g}$ pots were supplemented with an additional $15 \mathrm{~g}$, the $5 \mathrm{~g}$ pots were supplemented with an additional $10 \mathrm{~g}$, and the $10 \mathrm{~g}$ pots were supplemented with $5 \mathrm{~g}$ applied on the surface of each pot. A rate $(15 \mathrm{~g})$ higher than any recommended bag rate was chosen to supplement potential deficient treatments. Pots were drip irrigated using tap water at a rate that allowed media saturation and $\approx 25 \%$ leaching for 2 weeks, then hand watered for 4 weeks as needed. The experiment, consisting of four treatments and two cultivars was replicated 10 times with single pot replications (three plants in each pot) in a CRD. Individual plants were scanned from 10 pots per treatment for NDVI, atLEAF, and a SPAD chlorophyll meter 7, 14, 28, and $42 \mathrm{~d}$ after supplemented fertilizer was added. During measurements, the NDVI sensor was placed $45 \mathrm{~cm}$ above the plant canopy. For each pot, SPAD measurements were collected from four mature leaves from the bottom to middle area of plant. Leaf foliar analysis consisted of collecting the leaves used for the SPAD and atLEAF sensor with eight pots bulked per treatment for leaf $\mathrm{N}$ per treatment per cultivar each week.

Statistics. Continuous response variables of NDVI, SPAD, atLEAF, height, width, number of flowers, flower diameter, and shoot dry weight as well as the mentioned variables in SFT were analyzed using generalized linear mixed models methods with weekly repeated measurements. Data were analyzed using factorial design and the differences were contrasted using least significant difference (LSD, $P \leq 0.05$ ). Correlation analysis of fertilizer rates, NDVI, SPAD, atLEAF, and leaf $\mathrm{N}$ was also computed. Tests of significance were performed at the $0.05,0.01$, or 0.001 level using SAS/ STAT software, Version 9.3.

\section{Results}

Effects of cultivars and fertilizer rates on NDVI, SPAD, atLEAF, and leaf $N$ concentrations. Normalized Difference Vegetation Index values increased from 10 DAT to $17 \mathrm{DAT}$ in all $\mathrm{N}$ treatments across both cultivars then plateaued (Table 1). Values generally decreased from the previous week at 45 DAT with the exception of the control $(0 \mathrm{~g})$, which increased right before floral initiation and the plant still completely green (Table 1). The greatest NDVI value $(0.92)$ was observed at 24,31 , and 38 DAT, although there was no difference between the values of fertilizer rates except for the control treatments as well as the $5 \mathrm{~g}$ of fertilizer rate at 45 DAT in 'Jacqueline Yellow' (Table 1). 'Amico Bronze' showed the greatest NDVI value (0.92) with $15 \mathrm{~g}$ of $\mathrm{N}$ at $38 \mathrm{DAT}$, although was only different from the $0 \mathrm{~g}$ rate at $17,24,31,38$, and $45 \mathrm{DAT}$, the $5 \mathrm{~g}$ rate at 24,31 , and $38 \mathrm{DAT}$, and the $15 \mathrm{~g}$ rate at 17 DAT (Table 1).

Values for SPAD increased for all treatments at 10 DAT through 31 DAT with the exception of the $20 \mathrm{~g}$ rate at 10 DAT to 17 DAT (Table 2). Greatest SPAD values (49 and 39) were observed 38 DAT and 31 DAT in 'Jacqueline Yellow' and 'Amico Bronze', respectively (Table 2). However, SPAD values were not significantly different among the 10 , 15 , and $20 \mathrm{~g}$ fertilizer rates at $38 \mathrm{DAT}$ for 'Jacqueline Yellow' and the 15 and $20 \mathrm{~g}$ rates at 31 DAT for 'Amico Bronze' (Table 2). With increasing DATs, atLEAF values increased until 38 DA.T with the exceptions of $15 \mathrm{~g}$ fertilizer rate at 24 DAT in 'Jacqueline Yellow' and 0 and $20 \mathrm{~g}$ fertilizer rate at 24 DAT in 'Amico Bronze' and consequently decreased in most of the treatments in both cultivars at 45 DAT (Table 3 ). The greatest atLEAF value (0.55) was observed in the $15 \mathrm{~g}$ and $20 \mathrm{~g} \mathrm{~N}$ treatments 24, 38, and 45 DAT in 'Jacqueline Yellow' (Table 3). The greatest atLEAF value (0.50) was observed at 24 DAT for 'Amico Bronze' (Table 3).

Leaf $\mathrm{N}$ concentration decreased over time in both cultivars, but had increased with increasing fertilizer rates through 38 DAT (Table 4). NDVI values were significantly correlated $(P \leq 0.05$ and $P \leq 0.01)$ with leaf $\mathrm{N} 10$ DAT $(r=0.98$ and $r=0.97)$ in 'Jacqueline Yellow' and 'Amico Bronze', respectively (Table 5). In addition, NDVI values were significantly correlated with leaf $\mathrm{N}$ at $24 \mathrm{DAT}(r=0.93), 31 \mathrm{DAT}(r=0.89), 38$ DAT $(r=0.87)$, and 45 DAT $(r=0.88)$ in 'Amico Bronze' (Table 5). There was a significant $(P \leq 0.05$ and $P \leq 0.01)$ correlation among SPAD values and fertilizer rates at 10 and 17 DAT in 'Amico Bronze' and 38 and 45 DAT in 'Jacqueline Yellow' (Table 5). Leaf $\mathrm{N}$ was correlated with SPAD values 24 DAT in both cultivars (Table 5). The atLEAF values were not correlated with the values for SPAD, NDVI, fertilizer rates, and leaf $\mathrm{N}$ in both cultivars (Table 5). At 24, 31, and 45 DAT, both cultivars showed correlation between leaf $\mathrm{N}$ and fertilizer rates.

Final evaluation of plants showed the greatest values for number of flowers using 15 and $20 \mathrm{~g}$ fertilizer rates in 'Jacqueline Yellow' and $20 \mathrm{~g}$ fertilizer rate in 'Amico Bronze' (Table 6). The greatest values for flower diameter were observed using 10, 15, and $20 \mathrm{~g}$ fertilizer rates for 'Jacqueline Yellow' and 5, 10, 15, and $20 \mathrm{~g}$ fertilizer rates for 'Amico Bronze' (Table 6). Plant heights were greatest in the 10,15 , and $20 \mathrm{~g}$ fertilizer rates for 'Jacqueline Yellow' and the 15 and $20 \mathrm{~g}$ fertilizer rates for 'Amico Bronze' (Table 6). The greatest width value $(113 \mathrm{~cm})$ was observed with $15 \mathrm{~g}$ fertilizer rate in 'Jacqueline Yellow' and with the 15 and $20 \mathrm{~g}$ fertilizer rates in 'Amico Bronze' (Table 6). Shoot dry weight was greatest with the $20 \mathrm{~g}$ fertilizer rates for 'Jacqueline Yellow' and 'Amico Bronze', respectively (Table 6). Initially, the difference among heights and widths was not evident, but later increasing $\mathrm{N}$ produced taller and wider plants in both cultivars (Table 6).

Effects of additional fertilizer on NDVI, $S P A D$, at $L E A F$, leaf $N$ concentration values, and plant characteristics in 'Jacqueline Yellow' and 'Amico Bronze'. SFT showed that NDVI increased until 45 DAT in both cultivars (Table 7). Greatest NDVI value (0.92) was observed with $5(+10)$ and $10(+5)$ treatments, but were only different from the $0(+15)$ treatment at 38 and 45 DAT in 'Jacqueline Yellow'. There was no difference observed among the SFT treatments except for $0(+15)$ at 31 DAT in 'Amico Bronze' (Table 7). SPAD values increased with the greatest SPAD value (52) occurring 
Table 1. Normalized Difference Vegetation Index values for three plants in a single pot with different rates of fertilizer at different dates after fertilizer treatment during the vegetative stage in two chrysanthemum cultivars.

\begin{tabular}{lcllllll}
\hline Cultivar & Fertilizer rate $(\mathrm{g})$ & $1^{10 \mathrm{DAT}^{z}}$ & $17 \mathrm{DAT}$ & $24 \mathrm{DAT}$ & $31 \mathrm{DAT}$ & $38 \mathrm{DAT}$ & $45 \mathrm{DAT}$ \\
\hline Jacqueline Yellow & 0 & $0.76 \mathrm{bc}$ & $0.86 \mathrm{bc}$ & $0.86 \mathrm{~cd}$ & $0.87 \mathrm{bc}$ & $0.88 \mathrm{bc}$ & $0.89 \mathrm{bc}$ \\
& 5 & $0.81 \mathrm{ab}$ & $0.91 \mathrm{a}$ & $0.92 \mathrm{a}$ & $0.92 \mathrm{a}$ & $0.91 \mathrm{ab}$ & $0.88 \mathrm{~cd}$ \\
& 10 & $0.81 \mathrm{ab}$ & $0.91 \mathrm{a}$ & $0.91 \mathrm{ab}$ & $0.91 \mathrm{ab}$ & $0.91 \mathrm{ab}$ & $0.90 \mathrm{ab}$ \\
& 15 & $0.82 \mathrm{a}$ & $0.91 \mathrm{a}$ & $0.91 \mathrm{ab}$ & $0.92 \mathrm{a}$ & $0.92 \mathrm{a}$ & $0.91 \mathrm{a}$ \\
Amico Bronze & 20 & $0.82 \mathrm{a}$ & $0.89 \mathrm{ab}$ & $0.90 \mathrm{bc}$ & $0.92 \mathrm{a}$ & $0.92 \mathrm{a}$ & $0.91 \mathrm{a}$ \\
& 0 & $0.80 \mathrm{ab}$ & $0.87 \mathrm{c}$ & $0.88 \mathrm{~cd}$ & $0.88 \mathrm{~d}$ & $0.88 \mathrm{~cd}$ & $0.87 \mathrm{bc}$ \\
& 5 & $0.82 \mathrm{a}$ & $0.89 \mathrm{a}$ & $0.89 \mathrm{bc}$ & $0.89 \mathrm{bc}$ & $0.90 \mathrm{bc}$ & $0.89 \mathrm{ab}$ \\
& 10 & $0.82 \mathrm{a}$ & $0.89 \mathrm{a}$ & $0.90 \mathrm{ab}$ & $0.91 \mathrm{a}$ & $0.91 \mathrm{ab}$ & $0.91 \mathrm{a}$ \\
& 15 & $0.82 \mathrm{a}$ & $0.88 \mathrm{~b}$ & $0.91 \mathrm{a}$ & $0.91 \mathrm{a}$ & $0.92 \mathrm{a}$ & $0.91 \mathrm{a}$ \\
& 20 & $0.82 \mathrm{a}$ & $0.89 \mathrm{a}$ & $0.90 \mathrm{ab}$ & $0.90 \mathrm{ab}$ & $0.91 \mathrm{ab}$ & $0.91 \mathrm{a}$ \\
\hline
\end{tabular}

${ }^{2} \mathrm{DAT}=$ days after a topdressed pretreatment of 16-9-12 controlled-release fertilizer. Mean values $(n=10)$ followed by the same letter are not significant at $P \leq 0.05$ within cultivars and DAT using least significant differences $\left(\operatorname{LSD}_{0.05}\right)$.

Table 2. Soil Plant Analytical Development values for three plants in a single pot with different rates of fertilizer at different dates after fertilizer treatment during the vegetative stage in two chrysanthemum cultivars.

\begin{tabular}{lccccccc}
\hline Cultivar & Fertilizer rate $(\mathrm{g})$ & 10 DAT $^{\mathrm{z}}$ & $17 \mathrm{DAT}$ & $24 \mathrm{DAT}$ & $31 \mathrm{DAT}$ & $38 \mathrm{DAT}$ & $45 \mathrm{DAT}$ \\
\hline Jacqueline Yellow & 0 & $34 \mathrm{c}$ & $36 \mathrm{bc}$ & $38 \mathrm{~cd}$ & $40 \mathrm{de}$ & $39 \mathrm{~cd}$ & $38 \mathrm{de}$ \\
& 5 & $35 \mathrm{~b}$ & $40 \mathrm{ab}$ & $41 \mathrm{bc}$ & $42 \mathrm{~cd}$ & $43 \mathrm{bc}$ & $43 \mathrm{~cd}$ \\
& 10 & $35 \mathrm{~b}$ & $42 \mathrm{a}$ & $42 \mathrm{ab}$ & $43 \mathrm{bc}$ & $46 \mathrm{ab}$ & $45 \mathrm{bc}$ \\
Amico Bronze & 15 & $36 \mathrm{a}$ & $42 \mathrm{a}$ & $43 \mathrm{a}$ & $46 \mathrm{a}$ & $49 \mathrm{a}$ & $49 \mathrm{a}$ \\
& 20 & $36 \mathrm{a}$ & $35 \mathrm{~cd}$ & $41 \mathrm{bc}$ & $44 \mathrm{ab}$ & $49 \mathrm{a}$ & $46 \mathrm{ab}$ \\
& 0 & $32 \mathrm{c}$ & $33 \mathrm{c}$ & $33 \mathrm{c}$ & $35 \mathrm{~d}$ & $35 \mathrm{bc}$ & $34 \mathrm{bc}$ \\
& 5 & $33 \mathrm{~b}$ & $33 \mathrm{c}$ & $34 \mathrm{~b}$ & $36 \mathrm{bc}$ & $36 \mathrm{ab}$ & $35 \mathrm{ab}$ \\
& 10 & $33 \mathrm{~b}$ & $34 \mathrm{~b}$ & $35 \mathrm{a}$ & $36 \mathrm{bc}$ & $38 \mathrm{a}$ & $38 \mathrm{a}$ \\
& 15 & $35 \mathrm{a}$ & $35 \mathrm{a}$ & $35 \mathrm{a}$ & $39 \mathrm{a}$ & $38 \mathrm{a}$ & $35 \mathrm{ab}$ \\
& 20 & $35 \mathrm{a}$ & $35 \mathrm{a}$ & $35 \mathrm{a}$ & $37 \mathrm{ab}$ & $35 \mathrm{bc}$ & $35 \mathrm{ab}$ \\
\hline
\end{tabular}

${ }^{2} \mathrm{DAT}=$ days after a topdressed pretreatment of 16-9-12 controlled-release fertilizer. Mean values $(n=10)$ followed by the same letter are not significant at $P \leq 0.05$ within cultivars and DAT using least significant differences $\left(\operatorname{LSD}_{0.05}\right)$.

Table 3. atLEAF values for three plants in a single pot with different rates of fertilizer at different dates after fertilizer treatment during the vegetative stage in two chrysanthemum cultivars.

\begin{tabular}{lccccccc}
\hline Cultivar & Fertilizer rate $(\mathrm{g})$ & $10 \mathrm{DAT}^{\mathrm{z}}$ & $17 \mathrm{DAT}$ & $24 \mathrm{DAT}$ & $31 \mathrm{DAT}$ & $38 \mathrm{DAT}$ & $45 \mathrm{DAT}$ \\
\hline Jacqueline Yellow & 0 & $0.50 \mathrm{~b}$ & $0.49 \mathrm{~b}$ & $0.51 \mathrm{c}$ & $0.51 \mathrm{c}$ & $0.52 \mathrm{ab}$ & $0.48 \mathrm{bc}$ \\
& 5 & $0.45 \mathrm{~d}$ & $0.46 \mathrm{c}$ & $0.49 \mathrm{~d}$ & $0.52 \mathrm{~b}$ & $0.51 \mathrm{bc}$ & $0.51 \mathrm{ab}$ \\
& 10 & $0.48 \mathrm{c}$ & $0.49 \mathrm{~b}$ & $0.49 \mathrm{~d}$ & $0.51 \mathrm{c}$ & $0.51 \mathrm{bc}$ & $0.51 \mathrm{ab}$ \\
& 15 & $0.48 \mathrm{c}$ & $0.51 \mathrm{a}$ & $0.55 \mathrm{a}$ & $0.52 \mathrm{~b}$ & $0.51 \mathrm{bc}$ & $0.48 \mathrm{bc}$ \\
Amico Bronze & 20 & $0.51 \mathrm{a}$ & $0.51 \mathrm{a}$ & $0.52 \mathrm{~b}$ & $0.54 \mathrm{a}$ & $0.55 \mathrm{a}$ & $0.55 \mathrm{a}$ \\
& 0 & $0.39 \mathrm{bc}$ & $0.42 \mathrm{a}$ & $0.43 \mathrm{~b}$ & $0.42 \mathrm{c}$ & $0.41 \mathrm{de}$ & $0.41 \mathrm{a}$ \\
& 5 & $0.34 \mathrm{de}$ & $0.41 \mathrm{~b}$ & $0.41 \mathrm{bc}$ & $0.41 \mathrm{~d}$ & $0.44 \mathrm{ab}$ & $0.40 \mathrm{~b}$ \\
& 10 & $0.37 \mathrm{~cd}$ & $0.40 \mathrm{c}$ & $0.37 \mathrm{de}$ & $0.44 \mathrm{a}$ & $0.45 \mathrm{a}$ & $0.41 \mathrm{a}$ \\
& 15 & $0.41 \mathrm{a}$ & $0.42 \mathrm{a}$ & $0.39 \mathrm{~cd}$ & $0.43 \mathrm{~b}$ & $0.42 \mathrm{~cd}$ & $0.38 \mathrm{c}$ \\
& 20 & $0.40 \mathrm{ab}$ & $0.41 \mathrm{~b}$ & $0.50 \mathrm{a}$ & $0.42 \mathrm{c}$ & $0.43 \mathrm{bc}$ & $0.40 \mathrm{~b}$ \\
\hline
\end{tabular}

${ }^{2} \mathrm{DAT}=$ days after a topdressed pretreatment of 16-9-12 controlled-release fertilizer. Mean values $(n=10)$ followed by the same letter are not significant at $P \leq 0.05$ within cultivars and DAT using least significant differences $\left(\mathrm{LSD}_{0.05}\right)$.

Table 4. Leaf $\mathrm{N}$ concentration ( $\mathrm{g} \cdot \mathrm{kg}^{-1}$ dry weight) at different $\mathrm{N}$ rates in two chrysanthemum cultivars.

\begin{tabular}{lcclcccc}
\hline Cultivar & Fertilizer rate $(\mathrm{g})$ & $10 \mathrm{DAT}^{\mathrm{z}}$ & $17 \mathrm{DAT}$ & $24 \mathrm{DAT}$ & $31 \mathrm{DAT}$ & $38 \mathrm{DAT}$ & $45 \mathrm{DAT}$ \\
\hline Jacqueline Yellow & 0 & $2.40 \mathrm{~d}$ & $2.70 \mathrm{c}$ & $2.14 \mathrm{~d}$ & $2.48 \mathrm{~d}$ & $1.68 \mathrm{~d}$ & $1.60 \mathrm{~d}$ \\
& 5 & $4.37 \mathrm{c}$ & $4.80 \mathrm{~b}$ & $4.13 \mathrm{c}$ & $3.68 \mathrm{c}$ & $3.71 \mathrm{c}$ & $3.23 \mathrm{c}$ \\
& 10 & $4.99 \mathrm{~b}$ & $5.33 \mathrm{ab}$ & $5.33 \mathrm{~b}$ & $4.43 \mathrm{~b}$ & $5.25 \mathrm{a}$ & $4.30 \mathrm{~b}$ \\
& 15 & $5.33 \mathrm{a}$ & $5.41 \mathrm{a}$ & $5.62 \mathrm{a}$ & $5.38 \mathrm{a}$ & $5.39 \mathrm{a}$ & $4.42 \mathrm{~b}$ \\
Amico Bronze & 20 & $5.57 \mathrm{a}$ & $5.70 \mathrm{a}$ & $5.73 \mathrm{a}$ & $5.47 \mathrm{a}$ & $4.16 \mathrm{~b}$ & $5.07 \mathrm{a}$ \\
& 0 & $2.77 \mathrm{c}$ & $3.39 \mathrm{e}$ & $1.95 \mathrm{e}$ & $2.59 \mathrm{e}$ & $1.54 \mathrm{e}$ & $2.11 \mathrm{~d}$ \\
& 5 & $5.10 \mathrm{~b}$ & $5.33 \mathrm{~d}$ & $3.63 \mathrm{~d}$ & $3.68 \mathrm{~d}$ & $3.86 \mathrm{~d}$ & $4.59 \mathrm{c}$ \\
& 10 & $5.63 \mathrm{a}$ & $5.81 \mathrm{c}$ & $5.84 \mathrm{c}$ & $5.41 \mathrm{c}$ & $5.33 \mathrm{c}$ & $4.58 \mathrm{c}$ \\
& 15 & $5.74 \mathrm{a}$ & $6.19 \mathrm{~b}$ & $6.26 \mathrm{~b}$ & $6.03 \mathrm{~b}$ & $5.94 \mathrm{~b}$ & $5.68 \mathrm{~b}$ \\
& 20 & $5.74 \mathrm{a}$ & $6.62 \mathrm{a}$ & $6.72 \mathrm{a}$ & $6.69 \mathrm{a}$ & $7.04 \mathrm{a}$ & $6.91 \mathrm{a}$ \\
\hline
\end{tabular}

${ }^{2} \mathrm{DAT}=$ days after a topdressed pretreatment of 16-9-12 controlled-release fertilizer. Values are from combining five mature leaves and no petioles from 10 different pots per treatment for a single composite sample. Same leaves as used for the Soil Plant Analytical Development and atLEAF readings were collected for leaf $\mathrm{N}$ analysis except for the control treatment at 10 and 17 DAT.

with $10(+5) \mathrm{g}$ of $\mathrm{N}$ at $45 \mathrm{DAT}$ for 'Jacqueline Yellow'. The greatest SPAD sensor reading $(41)$ occurred using $0(+15), 5$ $(+10)$, and $10(+5)$ at 45,31 , and 38 DAT
Yellow' and 'Amico Bronze', respectively (Table 9). The greatest leaf $\mathrm{N}$ value $(5.57$ $\left.\mathrm{g} \cdot \mathrm{kg}^{-1} \mathrm{DW}\right)$ occurred using $10(+5) \mathrm{g}$ at 31 DAT for 'Jacqueline Yellow' (Table 10). Also, the greatest leaf $\mathrm{N}$ value with $(6.36$ $\left.\mathrm{g} \cdot \mathrm{kg}^{-1} \mathrm{DW}\right)$ occurred using $10(+5)$ at 45 DAT for 'Amico Bronze' (Table 10).

Supplemental fertilizer application to the control, $0(+15)$, increased leaf $\mathrm{N}$ concentration and flower diameter exceeding the other two supplemental treatments in 'Jacqueline Yellow' but not for flower number. For 'Amico Bronze', supplemental fertilizer application to the control, $0(+15)$, increased leaf $\mathrm{N}$ concentration only over the $5(+10)$ treatment and did not increase flower numbers over $5(+10)$ or $10(+5)$ treatments but did increase flower diameter over the $5(+10)$ treatment. Flower number was greatest using $10(+5) \mathrm{g}$ in both cultivars. There was no difference between SFT rates with using $0(+15) \mathrm{g}$ and $10(+5) \mathrm{g}$ for plant width in 'Jacqueline Yellow', while $10(+5) \mathrm{g}$ was the greatest value in 'Amico Bronze'. Shoot dry weight was greatest and not different between $5(+10)$ and $10(+5) \mathrm{g}$ in both cultivars (Table 11). No correlations were seen between SPAD, NDVI, atLEAF, fertilizer rates, and leaf N in SFT for both cultivars except at 38 DAT among leaf $\mathrm{N}$ and SPAD in 'Jacqueline Yellow'.

\section{Discussion}

Lunt and Kofranek (1958) found that maintaining a high level of $\mathrm{N}$ the first few weeks was essential for growing chrysanthemums. If a slight $\mathrm{N}$ deficiency is present at this time it can affect the size, color, and shape of the flowers and a supplemented application of $\mathrm{N}$ later may not compensate for the reduced growth of the plants. In this study, values for NDVI increased sharply from 10 DAT to 17 DAT in all fertilizer treatments across both cultivars (Table 1). NDVI cannot completely remove the background soil reflectance effects, because the information about vegetation canopies contained in the $1.24-\mu \mathrm{m}$ channel is very different from that contained in the red channel near $0.66 \mu \mathrm{m}$ and also underlying soil and other background reflectance (Gao, 1996; Wang et al., 2012b). After growth and expansion of plant size around $38 \mathrm{DAT}$, in general NDVI values decreased in value, which was also reported by Wang et al. (2012b) in potted geranium. This decrease may have been the result of floral initiation and a shift of carbohydrate resources.

With increasing days after treatment, SPAD values increased in all treatments and reached the greatest value $38 \mathrm{DAT}$ in both cultivars (Table 2). SPAD values increased progressively with fertilizer rates, in agreement with Piekielek and Fox (1992), Turner and Jund (1994), Wang et al. (2004), Wang et al. (2012a), and Zhu et al. (2012) (Table 2). There was no significant correlation between atLEAF values with fertilizer rates as well as the SPAD values for both cultivars, which contrasts with the results of Zhu et al. (2012) 
Table 5. Correlation coefficient $(r)$ matrix for measured sensor parameters and leaf nitrogen in two chrysanthemum cultivars.

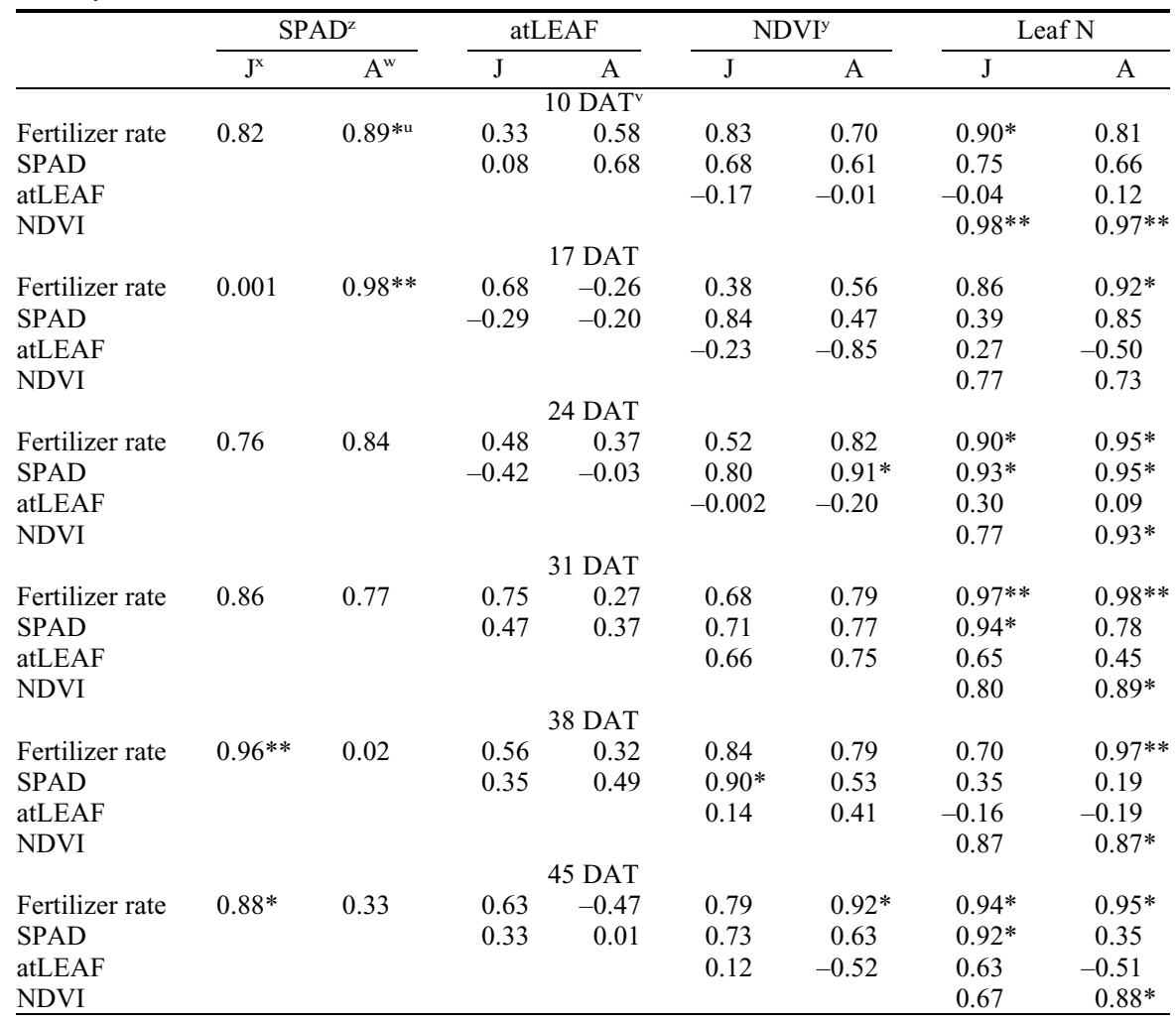

${ }^{\mathrm{z}}$ Soil Plant Analytical Development.

${ }^{y}$ Normalized Difference Vegetation Index.

“'Jacqueline Yellow'.

w'Amico Bronze'.

${ }^{\mathrm{v} D A T}=$ days after initial treatment of 16-9-12 controlled-release fertilizer.

"Representing Pearson's correlation coefficient $(r)$ significant at $P \leq 0.05\left(^{*}\right), P \leq 0.01\left({ }^{* *}\right)$, or $P \leq 0.001$ $(* * *)$.

Table 6. Final assessment measurements on plant parameters in two chrysanthemum cultivars $52 \mathrm{~d}$ after initial fertilizer application of 16-9-12 N-P-K controlled-release fertilizer.

\begin{tabular}{lcccccr}
\hline Cultivar & $\begin{array}{c}\text { Fertilizer } \\
\text { rate }(\mathrm{g})\end{array}$ & Flower no. & $\begin{array}{c}\text { Flower diam } \\
(\mathrm{cm})\end{array}$ & $\begin{array}{c}\mathrm{Ht} \\
(\mathrm{cm})\end{array}$ & $\begin{array}{c}\text { Width } \\
(\mathrm{cm})\end{array}$ & $\begin{array}{r}\text { Dry } \\
\text { wt }(\mathrm{g})\end{array}$ \\
\hline Jacqueline Yellow & 0 & $60 \mathrm{~d}^{z}$ & $2.86 \mathrm{c}$ & $15 \mathrm{c}$ & $53 \mathrm{e}$ & $10 \mathrm{~d}$ \\
& 5 & $65 \mathrm{c}$ & $3.25 \mathrm{~b}$ & $22 \mathrm{~b}$ & $66 \mathrm{~d}$ & $33 \mathrm{c}$ \\
& 10 & $118 \mathrm{~b}$ & $3.60 \mathrm{a}$ & $25 \mathrm{a}$ & $100 \mathrm{~b}$ & $36 \mathrm{~b}$ \\
& 15 & $148 \mathrm{a}$ & $3.50 \mathrm{ab}$ & $25 \mathrm{a}$ & $113 \mathrm{a}$ & $36 \mathrm{~b}$ \\
Amico Bronze & 20 & $148 \mathrm{a}$ & $3.65 \mathrm{a}$ & $24 \mathrm{a}$ & $96 \mathrm{c}$ & $54 \mathrm{a}$ \\
& 0 & $13 \mathrm{~d}$ & $2.85 \mathrm{bd}$ & $17 \mathrm{c}$ & $19 \mathrm{c}$ & $33 \mathrm{e}$ \\
& 5 & $72 \mathrm{c}$ & $3.25 \mathrm{ab}$ & $22 \mathrm{~b}$ & $45 \mathrm{~b}$ & $67 \mathrm{~d}$ \\
& 10 & $68 \mathrm{c}$ & $3.60 \mathrm{a}$ & $22 \mathrm{~b}$ & $48 \mathrm{~b}$ & $83 \mathrm{c}$ \\
& 15 & $86 \mathrm{~b}$ & $3.50 \mathrm{a}$ & $25 \mathrm{a}$ & $53 \mathrm{a}$ & $95 \mathrm{~b}$ \\
& 20 & $116 \mathrm{a}$ & $3.65 \mathrm{a}$ & $25 \mathrm{a}$ & $54 \mathrm{a}$ & $119 \mathrm{a}$ \\
\hline
\end{tabular}

${ }^{\mathrm{z}}$ Mean values $(n=10)$ followed by the same letter are not significant at $P \leq 0.05$ within cultivars and columns using least significant differences $\left(\mathrm{LSD}_{0.05}\right)$.

Table 7. Normalized Difference Vegetation Index with three plants in a single pot with different rates of supplemented fertilizer treatments (SFTs) added $30 \mathrm{~d}$ after initial fertilizer application in two chrysanthemum cultivars.

\begin{tabular}{lcccc}
\hline Cultivar & ${\text { SFT }(\mathrm{g})^{\mathrm{z}}}^{\mathrm{y}}$ & $31 \mathrm{DAT}^{\mathrm{y}}$ & $38 \mathrm{DAT}$ & $45 \mathrm{DAT}$ \\
\hline Jacqueline Yellow & $0(+15)$ & $0.88 \mathrm{ab}$ & $0.90 \mathrm{~b}$ & $0.90 \mathrm{~b}$ \\
& $5(+10)$ & $0.91 \mathrm{a}$ & $0.91 \mathrm{a}$ & $0.92 \mathrm{a}$ \\
Amico Bronze & $10(+5)$ & $0.91 \mathrm{a}$ & $0.91 \mathrm{a}$ & $0.92 \mathrm{a}$ \\
& $0(+15)$ & $0.89 \mathrm{~b}$ & $0.90 \mathrm{ab}$ & $0.92 \mathrm{a}$ \\
& $5(+10)$ & $0.90 \mathrm{a}$ & $0.91 \mathrm{a}$ & $0.91 \mathrm{ab}$ \\
& $10(+5)$ & $0.89 \mathrm{~b}$ & $0.90 \mathrm{ab}$ & $0.92 \mathrm{a}$ \\
\hline
\end{tabular}

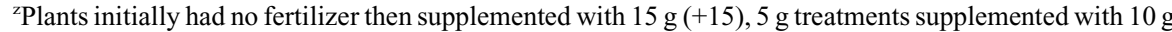
$(+10)$, and $10 \mathrm{~g}$ treatments supplemented with $5 \mathrm{~g}(+5)$.

${ }^{\mathrm{y}} \mathrm{DAT}=$ days after a pretreatment of $16-9-12$ controlled-release fertilizer. Mean values $(n=10)$ followed by the same letter are not significant at $P \leq 0.05$ within cultivars and columns by least significant differences $\left(\mathrm{LSD}_{0.05}\right)$. on canola (Brassica napus L.) and Dunn and Goad (2015) in ornamental cabbage (Brassica oleracea L. 'Tokyo Red'). Both SPAD and atLEAF measure transmittance through leaf surfaces in wavelengths associated with chlorophyll and both provide an indirect method for determining $\mathrm{N}$ status of crop canopies. At an early growth stage, chrysanthemum leaves are small making it hard to accurately determine what part of the leaf was being sensed in the sensor slot area. Dunn and Goad (2015) showed that sensor sampling location within a leaf affected SPAD and atLEAF readings for 'Tokyo Red'. It has also been reported for some crops that leaf chlorophyll content may vary with cultivar (Debaeke et al., 2006), growth stages (Ziadi et al., 2010), leaf thickness (Peng et al., 1993), sampling procedure (Olfs et al., 2005; Peterson et al., 1993), and deficiency of nutrients other than N (Masoni et al., 1996), which may account for the variability among sensor readings.

Correlation analysis regardless of weeks (DAT) overall showed correlations $(P \leq 0.05$ and $P \leq 0.01)$ among leaf $\mathrm{N}$ and fertilizer rates, fertilizer rates and SPAD, and SPAD with NDVI and atLEAF (Table 5). Correlation of NDVI with leaf $\mathrm{N}$ at 10 DAT indicates that the NDVI sensor is able to distinguish among fertilizer treatments early using three cuttings per pot even before the plant canopy completely fills the pot $(\approx 45 \%$ soil coverage $)$ at 24 DAT.

The greatest values for number of flowers occurred using 15 and $20 \mathrm{~g}$ fertilizer rates in 'Jacqueline Yellow' and $20 \mathrm{~g}$ rate in 'Amico Bronze' (Table 6). In contrast with the data by Ying and Joiner (1960) on the number of flowers, fertilizer rates had a positive correlation with the number of flowers in this study (Table 6). The result showed two and a half times more flowers were produced using 20 and $15 \mathrm{~g} \mathrm{~N}$ in comparison with the control treatment in 'Jacqueline Yellow' and almost nine times more flowers with using the $20 \mathrm{~g}$ of fertilizer in 'Amico Bronze'.

Applied fertilizer is commonly used very inefficiently, with only $30 \%$ to $40 \%$ of the $\mathrm{N}$ being absorbed by the crop and the rest lost through leaching, denitrification, volatilization, soil erosion, and microbial consumption (Glass, 2003; Raun and Johnson, 1999). Today, there is considerable pressure to reduce the use of $\mathrm{N}$ because of rising fuel costs and the risks of contaminating the water, although this can often conflict with the need for greater crop yields and plant quality (Glass, 2003; Nelson, 2009). Nitrogen is normally easily leached and many growers prefer slowly available forms of this element. Elliott and Nelson (1983) reported that chrysanthemums accumulate large quantities of $\mathrm{N}$ early as grown in a nutrient solution accumulated $\approx 42 \%$ of the total-N $\left(\mathrm{NO}_{3}{ }^{-}\right.$and with $\left.\mathrm{NH}_{4}{ }^{+}\right)$after the first $9 \mathrm{~d}$ and $30 \%$ in the subsequent $21 \mathrm{~d}$. The additional supplemental fertilizer results showed only a marginal improvement in plant quality and salability indicating that additional fertilizer may need to be added earlier in production 
Table 8. Soil Plant Analytical Development with three plants in a single pot with different rates of $\mathrm{N}$ with supplemented fertilizer treatments (SFTs) added $30 \mathrm{~d}$ after initial fertilizer application in two chrysanthemum cultivars.

\begin{tabular}{lcccc}
\hline Cultivar & ${\text { SFT }(\mathrm{g})^{\mathrm{z}}}$ & $31 \mathrm{DAT}^{\mathrm{y}}$ & $38 \mathrm{DAT}$ & $45 \mathrm{DAT}$ \\
\hline Jacqueline Yellow & $0(+15)$ & $37 \mathrm{c}$ & $49 \mathrm{a}$ & $50 \mathrm{c}$ \\
& $5(+10)$ & $39 \mathrm{~b}$ & $38 \mathrm{bc}$ & $51 \mathrm{~b}$ \\
Amico Bronze & $10(+5)$ & $40 \mathrm{a}$ & $45 \mathrm{ab}$ & $52 \mathrm{a}$ \\
& $0(+15)$ & $34 \mathrm{~b}$ & $40 \mathrm{~b}$ & $41 \mathrm{a}$ \\
& $5(+10)$ & $41 \mathrm{a}$ & $39 \mathrm{c}$ & $38 \mathrm{c}$ \\
& $10(+5)$ & $40 \mathrm{ab}$ & $41 \mathrm{a}$ & $39 \mathrm{~b}$ \\
\hline
\end{tabular}

Plants initially had no fertilizer then supplemented with $15 \mathrm{~g}(+15), 5 \mathrm{~g}$ treatments supplemented with $10 \mathrm{~g}$ $(+10)$, and $10 \mathrm{~g}$ treatments supplemented with $5 \mathrm{~g}(+5)$.

${ }^{\mathrm{y}} \mathrm{DAT}=$ days after a pretreatment of 16-9-12 controlled-release fertilizer. Mean values $(n=10)$ followed by the same letter are not significant at $P \leq 0.05$ within cultivars and columns by least significant differences $\left(\mathrm{LSD}_{0.05}\right)$.

Table 9. atLEAF values with three plants in a single pot with different rates of fertilizer with supplemented fertilizer treatments (SFTs) added $30 \mathrm{~d}$ after initial fertilizer application in two chrysanthemum cultivars.

\begin{tabular}{lcccc}
\hline Cultivar & SFT $(\mathrm{g})^{\mathrm{z}}$ & $31 \mathrm{DAT}^{\mathrm{z}}$ & $38 \mathrm{DAT}$ & $45 \mathrm{DAT}$ \\
\hline Jacqueline Yellow & $0(+15)$ & $0.48 \mathrm{a}$ & $0.51 \mathrm{~b}$ & $0.55 \mathrm{ab}$ \\
& $5(+10)$ & $0.48 \mathrm{a}$ & $0.51 \mathrm{~b}$ & $0.53 \mathrm{c}$ \\
Amico Bronze & $10(+5)$ & $0.45 \mathrm{~b}$ & $0.52 \mathrm{a}$ & $0.56 \mathrm{a}$ \\
& $0(+15)$ & $0.41 \mathrm{a}$ & $0.41 \mathrm{~b}$ & $0.44 \mathrm{~b}$ \\
& $5(+10)$ & $0.41 \mathrm{a}$ & $0.42 \mathrm{a}$ & $0.45 \mathrm{a}$ \\
& $10(+5)$ & $0.40 \mathrm{~b}$ & $0.42 \mathrm{a}$ & $0.45 \mathrm{a}$ \\
\hline
\end{tabular}

ㄱants initially had no fertilizer then supplemented with $15 \mathrm{~g}(+15), 5 \mathrm{~g}$ treatments supplemented with $10 \mathrm{~g}$ $(+10)$, and $10 \mathrm{~g}$ treatments supplemented with $5 \mathrm{~g}(+5)$.

${ }^{\mathrm{y}} \mathrm{DAT}=$ days after a pretreatment of $16-9-12$ controlled-release fertilizer. Mean values $(n=10)$ followed by the same letter are not significant at $P \leq 0.05$ within cultivars and columns by least significant differences $\left(\mathrm{LSD}_{0.05}\right)$.

Table 10. Leaf $\mathrm{N}$ concentration $\left(\mathrm{g} \cdot \mathrm{kg}^{-1}\right.$ dry weight) for three supplemental fertilizer treatments (SFT) added $30 \mathrm{~d}$ after initial fertilizer application in two chrysanthemum cultivars.

\begin{tabular}{lcccc}
\hline Cultivar & SFT $(\mathrm{g})^{\mathrm{z}}$ & $31 \mathrm{DAT}^{\mathrm{y}}$ & $38 \mathrm{DAT}$ & $45 \mathrm{DAT}$ \\
\hline Jacqueline Yellow & $0(+15)$ & $5.40 \mathrm{a}$ & $5.23 \mathrm{a}$ & $5.45 \mathrm{a}$ \\
& $5(+10)$ & $5.22 \mathrm{a}$ & $5.00 \mathrm{~b}$ & $4.64 \mathrm{c}$ \\
Amico Bronze & $10(+5)$ & $5.57 \mathrm{a}$ & $4.66 \mathrm{c}$ & $4.92 \mathrm{~b}$ \\
& $0(+15)$ & $5.73 \mathrm{a}$ & $5.77 \mathrm{a}$ & $5.92 \mathrm{~b}$ \\
& $5(+10)$ & $5.79 \mathrm{a}$ & $5.87 \mathrm{a}$ & $5.72 \mathrm{c}$ \\
& $10(+5)$ & $5.78 \mathrm{a}$ & $5.79 \mathrm{a}$ & $6.36 \mathrm{a}$ \\
\hline
\end{tabular}

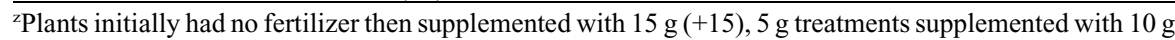
$(+10)$, and $10 \mathrm{~g}$ treatments supplemented with $5 \mathrm{~g}(+5)$.

${ }^{y} \mathrm{DAT}=$ days after a pretreatment of 16-9-12 controlled-release fertilizer. Same leaves as used for the SPAD and atLEAF readings were collected for leaf $\mathrm{N}$ analysis.

Table 11. Final assessment measurements on plant parameters $52 \mathrm{~d}$ after supplemented fertilizer treatments (SFTs) added in two chrysanthemum cultivars.

\begin{tabular}{lcccccc}
\hline Cultivar & SFT $(\mathrm{g})^{\mathrm{z}}$ & Flower no. & Flower diam $(\mathrm{cm})$ & $\mathrm{Ht}(\mathrm{cm})$ & Width $(\mathrm{cm})$ & Dry wt $(\mathrm{g})$ \\
\hline Jacqueline Yellow & $0(+15)$ & $62 \mathrm{c}^{\mathrm{y}}$ & $3.90 \mathrm{a}$ & $22 \mathrm{~b}$ & $62 \mathrm{ab}$ & $31 \mathrm{~b}$ \\
& $5(+10)$ & $132 \mathrm{~b}$ & $3.50 \mathrm{~b}$ & $24 \mathrm{a}$ & $59 \mathrm{~b}$ & $45 \mathrm{a}$ \\
& $10(+5)$ & $155 \mathrm{a}$ & $3.25 \mathrm{~b}$ & $25 \mathrm{a}$ & $64 \mathrm{a}$ & $46 \mathrm{a}$ \\
Amico Bronze & $0(+15)$ & $52 \mathrm{c}$ & $4.35 \mathrm{a}$ & $25 \mathrm{a}$ & $54 \mathrm{~b}$ & $70 \mathrm{~b}$ \\
& $5(+10)$ & $87 \mathrm{~b}$ & $3.50 \mathrm{~b}$ & $26 \mathrm{a}$ & $42 \mathrm{c}$ & $92 \mathrm{a}$ \\
& $10(+5)$ & $100 \mathrm{a}$ & $4.10 \mathrm{a}$ & $26 \mathrm{a}$ & $61 \mathrm{a}$ & $94 \mathrm{a}$ \\
\hline
\end{tabular}

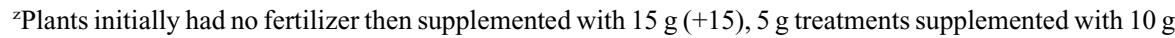
$(+10)$, and $10 \mathrm{~g}$ treatments supplemented with $5 \mathrm{~g}(+5)$.

y Mean values $(n=10)$ followed by the same letter are not significant at $P \leq 0.05$ within cultivars and columns by least significant differences $\left(\mathrm{LSD}_{0.05}\right)$.

or in greater quantity as indicated by the increased flowering and shoot dry weights for the $20 \mathrm{~g}$ rate. Plants that were evaluated from the $10(+5) \mathrm{g}$ treatment showed higher flower number in the final assessment than plants with the normal $\mathrm{N}$ fertilization of 10 or $15 \mathrm{~g}$ in both cultivars and $20 \mathrm{~g}$ for 'Jacqueline Yellow' (Tables 6 and 11). Splitting fertilizer application may help to reduce $\mathrm{N}$ leaching. The result confirms the
atLEAF sensors showed a greater ability to separate among fertilizer rates; however, separation was not consistent among dates and cultivars making $\mathrm{N}$ management decisions difficult. Future research should investigate SFT rates and timing in relation to sensor readings and developing an efficient protocol for sensor and leaf sampling procedures.

\section{Literature Cited}

Ali, H. 2010. Fundamentals of irrigation and onfarm water management: Vol. 1, Springer. ISBN 978-1-4419-6335-2.

Baghzouz, M., D.A. Devitt, and R.L. Morris. 2007. Assessing canopy spectral reflectance of hybrid bermudagrass under various combinations of nitrogen and water treatments. Appl. Eng. Agr. 23:763-774.

Bell, G.E., B.M. Howell, G.V. Johnson, W.R Raun, J.B. Solie, and M.L. Stone. 2004. Optical sensing of turfgrass chlorophyll content and tissue nitrogen. HortScience 39:1130-1132.

Blackmer, T.M. and J.S. Schepers. 1995. Use of a chlorophyll meter to monitor nitrogen status and schedule fertigation for corn. J. Prod. Agr. 8:56-60.

Carrillo, T. 2006. Normalized difference vegetative index, arthropod density, water and nitrogen interactions in ACALA 1517-99 cotton, Gossypium hirsutum (L.). PhD diss., New Mexico State University, Las Cruces, NM.

Clay, D.E., K. Kim, J. Chang, S.A. Clay, and K. Dalsted. 2006. Characterizing water and nitrogen stress in corn using remote sensing. Agron. J. 98:579-587.

Debaeke, P., P. Rouet, and E. Justes. 2006. Relationship between the normalized SPAD index and the nitrogen nutrition index: Application to durum wheat. J. Plant Nutr. 29:75-92.

Dunn, B.L. and C. Goad. 2015. Effect of foliar nitrogen and optical sensor sampling method and location for determining ornamental cabbage fertility status. HortScience 50:74-77.

Dunn, B.L., A. Shrestha, C. Goad, and A.A. Khoddamzadeh. 2015. Use of optical sensors to assess Gaillardia Foug. nitrogen status. J. Appl Hort. 17(3):181-185.

Eitel, J., D.S. Long, P.E. Gessler, and E.R. Hunt. 2008. Combined spectral index to improve ground-based estimates of nitrogen status in dryland wheat. Agron. J. 100:1694-1702.

El-Shikha, D.M., P. Waller, D. Hunsaker, T. Clarke, and E. Barnes. 2007. Ground-based remote sensing for assessing water and nitrogen status of broccoli. Agr. Water Mgt. 92:183-193.

Elliott, G.C. and P.V. Nelson. 1983. Relationships among nitrogen accumulation, nitrogen assimilation and plant growth in chrysanthemums. Physiol. Plant. 57:250-259.

Filella, I., L. Serrano, J. Serra, and J. Penuelas. 1995. Evaluating wheat nitrogen status with canopy reflectance indices and discriminant analysis. Crop Sci. 35:1400-1405.

Gao, B.C. 1996. NDWI-A normalized difference water index for remote sensing of vegetation liquid water from space. Remote Sens. Environ. 58:257-266.

theory that giving plants a longer period to grow and expand the root system after $\mathrm{N}$ startup, can help the plants to absorb more $\mathrm{N}$ in an additional fertilizer stage. Based on flower number and dry weight for both species and one fertilizer application rate, $20 \mathrm{~g}$ would be recommended. The NDVI sensor was only able to distinguish between the control and fertilizer rates, but not within different fertilizer rates. The SPAD and
Glass, A.D.M. 2003. Nitrogen use efficiency of crop plants: Physiological constraints upon nitrate absorption. Crit. Rev. Plant Sci. 22:453-470.

Hardin, J.A., M.W. Smith, P.R. Weckler, and B.S. Cheary. 2012. In situ measurement of pecan leaf nitrogen concentration using a chlorophyll meter and vis-near infrared multispectral camera. HortScience 47:955-960. 
Hawkins, J.A., J.E. Sawyer, D.W. Barker, and J.P. Lundvall. 2007. Using relative chlorophyll meter values to determine nitrogen application rates for corn. Agron. J. 99:1034-1040.

Johansen, B. and H. Tømmervik. 2014. The relationship between phytomass, NDVI and vegetation communities on Svalbard. Intl. J. Appl. Earth Obs. Geoinf. 27A:20-30.

Lunt, O.R. and A.M. Kofranek. 1958. Nitrogen and potassium nutrition of chrysanthemums. Proc. Amer. Soc. Hortic. Sci. 72:487-497.

Masoni, A., L. Ercoli, and M. Mariotti. 1996. Spectral properties of leaves deficient in iron, sulphur, magnesium, and manganese. Agron. J. 88:937-943.

Moorby, J. and R.T. Besford. 1983. Mineral nutrition and growth, p. 481-529. In: A. Lauchi and R.L. Bieleski (eds.). Inorganic plant nutrition. Encycl. Plant Physiol. New Series. SpringerVerlag, Berlin, Germany.

Nelson, A. 2009. Greenhouse technology saves on input costs. 18 Nov. 2015. <http://www.thepacker. $\mathrm{com} /$ fruit-vegetable-news/shipping-profiles/ western-reenhouse-vegetables/greenhouse technology_saves_on_input_costs_122156019. $\mathrm{html}>$.

Olfs, H.W., K. Blankenau, F. Brentrup, J. Jasper, A. Link, and J. Lammel. 2005. Soil and plant-based nitrogen fertilizer recommendations in arable farming. J. Plant Nutr. Soil Sci. 168:414-431.

Peng, S., F.V. Garcia, R.C. Laza, and K.G. Cassman. 1993. Adjustment for specific leaf weight improves chlorophyll meter's estimate of rice leaf nitrogen concentration. Agron. J. 85:987-990.

Penũelas, J., J.A. Gamon, A.L. Fredeen, J. Merino, and C.B. Field. 1994. Reflectance indices associated with physiological changes in nitrogen and water-limited sunflower leaves. Remote Sens. Environ. 48:135-146.
Peterson, T.A., T.M. Blackmer, D.D. Francis, and J.S. Schepers. 1993. Using a chlorophyll meter to improve N management. Nebguide G93-1171A. Coop. Ext. Serv., University of Nebraska, Lincoln, NE.

Piekielek, W.P. and R.H. Fox. 1992. Use of a chlorophyll meter to predict side dress nitrogen requirements for maize. Agron. J. 84:59-65.

Raun, W.R. and G.V. Johnson. 1999. Improving nitrogen use efficiency for cereal production. Agron. J. 91:357-363.

Richardson, A.D., S.P. Duigan, and G.P. Berlyn. 2002. An evaluation of noninvasive methods to estimate foliar chlorophyll content. New Phytol. 153:185-194.

Seemann, J.R., T.D. Sharkey, J. Wang, and C.B. Osmond. 1987. Environmental effects on photosynthesis, nitrogen-use efficiency, and metabolite pools in leaves of sun and shade plants. Plant Physiol. 84:796-802.

Shaahan, M.M., A.A. El-Sayed, and A.A.A. ElNour. 1999. Predicting nitrogen, magnesium, and iron nutritional status in some perennial crops using a portable chlorophyll meter. Sci. Hort. 82:339-348.

Turner, F.T. and M.F. Jund. 1994. Assessing the nitrogen requirements of rice crops with a chlorophyll meter. Austral. J. Expt. Agr. 34:1001-1005.

U.S. Department of Agriculture. 2013. Floriculture crops 2012 summary. ISSN: 1949-0917 p. 34.

Wang, Q., J. Chen, and Y. Li. 2004. Nondestructive and rapid estimation of leaf chlorophyll and nitrogen status of peace lily using a chlorophyll meter. J. Plant Nutr. 27:557-569.

Wang, Y., B.L. Dunn, and D.B. Arnall. 2012a. Assessing nitrogen status in potted geranium through discriminant analysis of ground-based spectral reflectance data. HortScience 47: 343-348.
Wang, Y., B.L. Dunn, D.B. Arnall, and P. Mao. $2012 \mathrm{~b}$. Use of an active canopy sensor and SPAD chlorophyll meter to quantify geranium nitrogen status. HortScience 47:45-50.

Westerveld, S.M., A.W. McKeown, C.D. ScottDupree, and M.R. McDonald. 2003. Chlorophyll and nitrate meters as nitrogen monitoring tools for selected vegetables in southern Ontario. Acta Hort. 627:259-266.

Xia, Y., X. Deng, P. Zhou, K. Shima, and J.A. Teixeira da Silva. 2006. The world floriculture industry: Dynamics of production and markets, p. 336-347. In: J.A. Teixeira da Silva (ed.). Floriculture, ornamental and plant biotechnology: Advances and topical issues, 1st ed., Volume IV. Global Science Books, Ltd., Isleworth, UK.

Xiong, X., G.E. Bell, J.B. Solie, M.W. Smith, and B. Martin. 2007. Bermudagrass seasonal responses to nitrogen fertilization and irrigation detected using optical sensor. Crop Sci. 47: 1603-1610.

Ying, H.K. and J.N. Joiner. 1960. The effect of sources and levels of nitrogen on the growth and flowering of potted chrysanthemums. Florida State Hort. Soc. p. 401-404.

Zanin, G. and P. Sambo. 2006. Using SPADmeter in nitrogen fertilization of Rosa chinensis Jacq. var. mutabilis. HortScience 41: 969-970.

Zhu, J., N. Tremblay, and Y. Liang. 2012. Comparing SPAD and atLEAF values for chlorophyll assessment in crop species. Can. J. Soil Sci. 92:645-648.

Ziadi, N., G. Belanger, A. Claessens, L. Lefebvre, N. Tremblay, A.N. Cambouris, M.C. Nolin, and L.E. Parent. 2010. Plant-based diagnostic tools for evaluating wheat nitrogen status. Crop Sci. 50:2580-2590. 